\title{
HUBUNGAN KARAKTER DENGAN MINAT MAHASISWA KEBIDANAN STIKES BINA USADA MENJADI ENTERPRENEUR
}

\author{
I Gede Wirajaya, Alfiery Leda Kio, Nina Rismawati Hakim
}

STIKES Bina Usada Bali, Jl. Kubu Gunung, Tegal Jaya, Dalung, Badung, Bali

E-mail: kioalfieryleda@gmail.com

\begin{abstract}
Midwifery is one of many professions in the world of health assigned to help the process of labor for mothers, including the caregiving during the childbirth and has as well become the only profession to assist women in the pre and post-labor. The large amount of midwife graduates as counted in every year is contributing in the increasing number of unemployment in Indonesia. For those who had been graduated as a midwife in addition with specific skills of taking care for mothers before and after the birth giving, must have not been unemployed after being equipped with the knowledge of entrepreneurship as there should be an opportunity to create business and new job fields for others. The cross-sectional design was implemented in this research by applying quantitative method of approach. The data were collected in September 2019 through questionnaire distributed to 39 students of midwifery. The data analysis included Kendall's Tau univariate and bivariate analysis. The univariate analysis showed that most students had moderate characteristics for entrepreneurship numbered 16 of the total students (43.2\%) and those with high interest in entrepreneurship was in the number of 18 students (48.6\%). Meanwhile, the bivariate analysis with Kendall Tau's correlation value of -0.775 showed the presence of weak level of correlation with the value of $p=0.00$ less than $a=0.05(p<0.05)$ meaning that there was significant relation between the education of entrepreneurship and the interest in becoming entrepreneurs of the midwifery students of STIKES Bina Usada Bali.
\end{abstract}

Keywords: Entrepreneurship Lectures, Entrepreneurs Interest, Midwifery.

\begin{abstract}
Abstrak
Bidan merupakan salah satu profesi dalam dunia kesehatan yang memiliki tugas untuk membantu proses melahirkan pada seorang ibu, memberi asuhan pada masa persalinan dan menjadi satu-satunya profesi yang memiliki tugas untuk merawat seorang wanita yang akan melahirkan dan juga setelah melahirkan. Banyaknya lulusan bidan setiap tahunnya menjadi salah satu penyebab meningkatnya jumlah pengangguran di Indonesia. Lulusan bidan yang sudah memiliki kemampuan yang khusus dalam bidang pengasuhan dan perawatan seorang ibu yang sedang mengandung dan setelah melahirkan, seharusnya tidak menjadi pengangguran ketika mereka dibekali pengetahuan tentang entrepreneurship, karena mereka dapat membangun usaha mereka sendiri dan bahkan mampu membuka lapangan pekerjaan. STIKES Bina Usada Bali menambahkan mata kuliah entrepreneurship sebagai salah satu mata kuliah yang wajib diambil oleh mahasiswa untuk memberikan pandangan baru kepada mahasiswa. Penelitian ini bertujuan untuk melihat pengaruh pendidikan entrepreneurship terhadap minat mahasiswa kebidanan STIKES Bina Usada Bali menjadi seorang entrepreneur. Penelitian menggunakan rancangan cross-sectional dengan pendekatan kuantitatif. Pengumpulan data dilakukan pada bulan September 2019 melalui pengisian kuesioner oleh 39 mahasiswa kebidanan. Analisis data dengan analisis univariat dan bivariat. Analisis univariat menunjukkan hasil mayoritas responden memiliki karakter entrepreneur sedang sebanyak 16 mahasiswa $(43,2 \%)$ dan mahasiswa yang memiliki minat tinggi menjadi entrepreneur sebanyak 18 mahasiswa (48,6\%\%). Analisis bivariat dengan nilai korelasi Kendall's Tau sebesar - 0,775 menunjukkan adanya tingkat hubungan yang lemah dengan nilai $\mathrm{p}=0,00$ lebih kecil dari $\alpha=0,05(\mathrm{p}<0,05)$ yang berarti ada hubungan yang signifikan antara pendidikan entrepreneurship dengan minat mahasiswa kebidanan STIKES Bina Usada Bali menjadi entrepreneur.
\end{abstract}


Kata Kunci: Kuliah Entrepreneurship, Minat Entrepreneur, Bidan.

\section{Pendahuluan}

Bidan merupakan salah satu profesi dalam dunia kesehatan yang memiliki tugas untuk membantu proses melahirkan pada seorang ibu, memberi asuhan pada masa persalinan dan menjadi salah satu profesi yang memiliki tugas untuk merawat seorang wanita yang akan melahirkan dan juga setelah melahirkan. Pada tahun 2014 Majelis Tenaga Kesehatan Indonesia mencatat bidan yang memiliki Surat Tanda Registrasi (STR) sebanyak 280.263 (dpr.go.id). Jumlah bidan yang aktif bekerja sebagai Pegawai Tidak Tetap (PTT) per tahun 2018 sebanyak 4.084 (Data \& Informasi Profil Kesehatan Indonesia, 2018). Setiap tahunnya banyak Universitas dan Sekolah Tinggi yang meluluskan mahasiswa jurusan kebidanan, pada tahun 2016 sebanyak 4.639 mahasiswa, tahun 2017 sebanyak 4.135, dan menurut Data \& Informasi Profil Kesehatan Indonesia (2018) pada tahun 2018 sebanyak 3.903 mahasiswa lulus dan ini menjadi suatu masalah tersendiri ketika mereka memulai untuk melamar pekerjaan di rumah sakit, bidan praktek, atau beberapa instansi pemerintah lainnya, pada waktu bersamaan lapangan pekerjaan yang tersedia sangatlah sedikit. Untuk menanggulangi permasalahan tersebut, penting bagi lulusan bidan untuk diberikan bekal tentang entrepreneurship.

Minat untuk menjadi seorang entrepreneur dapat tumbuh ketika mahasiswa diberikan pengetahuan tentang entrepreneurship. Minat merupakan rasa suka dan rasa keterikatan yang lebih pada suatu hal atau aktivitas, tanpa suruhan (Djaali, 2007). Menurut Kashmir (2013) orang yang memiliki kemampuan untuk menciptakan hal yang sebelumnya belum pernah ada, atau menciptakan sesuatu yang berbeda dari yang ada sebelumnya disebut dengan entrepreneur. Berdasarkan data BPS tahun 2016 dari jumlah penduduk sebesar 252 juta, jumlah wirausaha non pertanian yang konsisten mencapai 7,8 juta orang atau 3,1\% (depkop,2017). Menurut Wirajaya (2018), dalam peneletiannya yang berjudul "Pengaruh Kuliah Entrepreneurship Terhadap Minat Mahasiswa Keperawatan STIKES Bina Usada Angkatan VIII Menjadi Seorang Entrepreneur" bertumbuhnya entrepreneur tidak lepas dari peran masyarakat dan pemerintah dengan kebijakannya serta swasta dan kalangan mahasiswa atau kampus.

Pemerintah saat ini sedang gencar mengajak masyarakat khususnya sarjana - sarjana yang baru lulus untuk menjadi seorang entrepreneur sehingga dapat mengurangi angka pengangguran di Indonesia.
Melihat hal tersebut untuk membantu program pemerintah, STIKES Bina Usada Bali menambahkan mata kuliah entrepreneurship sebagai salah satu mata kuliah yang wajib diambil oleh mahasiswa. Berdasarkan hasil tanya jawab selama proses pembelajaran entrepreneurship, masih banyak mahasiswa kebidanan yang berencana untuk melamar pekerjaan di rumah sakit, klinik, dan tempat pelayanan kesehatan lainnya. Padahal mereka memiliki peluang untuk menjadi entrepreneur di bidang kesehatan misalnya dengan membuka home care yang berfokus kepada pelayanan ibu - ibu yang baru saja melahirkan, dan mungkin membuka praktek bidan mandiri.

Dari pembahasan latar belakang diatas peneliti tertarik melakukan penelitian tentang hubungan karakter entrepreneurship terhadap minat mahasiswa kebidanan STIKES Bina Usada Bali menjadi seorang entrepreneur.

\section{Metode}

Penelitian ini adalah penelitian korelasional dan dengan desain penelitian yaitu cross-sectional yang merupakan jenis penelitian yang menitikberatkan pada pengukuran data variabel independen dan dependen dilakukan pada satu waktu. Pada jenis ini, Penilaian kedua variable ini dilakukan secara simultan. Bukan berarti pada waktu yang sama semua subjek penelitian diobservasi, akan tetapi yang dilihat adalah dari penilaian variabelnya yaitu dinilai hanya satu kali (Nursalam, 2013).

Populasi adalah seluruh jumlah obyek/subyek yang mempunyai kualitas dan karakteristik tertentu (Sugiyono, 2014). Populasi dalam penelitian ini adalah seluruh mahasiswa kebidanan tahun 2019 STIKES Bina Usada Bali sebanyak 37 mahasiswa. Sampel adalah bagian populasi tersebut baik dari jumlah dan karakteristik yang dimiliki. Sampel adalah bagian populasi terjangkau yang bisa digunaka sebagai responden melalui sampling (Sugiyono, 2014). Sampel dalam penelitian ini diambil dengan total sampling yaitu seluruh populasi dijadikan responden yaitu sebanyak 37 mahasiswa.

Untuk memperoleh informasi dari responden dilakukan pengumpulan data melalui instrumen penelitian berupa kuesioner. Terdapat 2 kuesioner yang digunakan oleh peneliti yaitu kuesioner karakter entrepreneur yang terdiri dari 12 pernyataan dan kuesioner minat entrepreneur yang terdiri dari 6 pernyataan menggunakan skala Likert dengan kategori skor: 4 = Sangat setuju (SS), 3 = 
Setuju (S), 2 = Tidak setuju (TS), 1 = Sangat tidak setuju (STS). Jumlah skor dari pernyataan item tersebut memiliki makna $X \leq \mu-0,5 \sigma$ (rendah), $\mu$ $0,5 \sigma<\mathrm{X} \leq \mu+0,5 \sigma$ (sedang), dan $\mu+0,5 \sigma>\mathrm{X}$ (tinggi) (Azwar, 2009).

Pengumpulan data dilakukan pada bulan September 2019. Pengambilan data kepada responden di STIKES Bina Usada Bali dilakukan saat mahasiswa sedang istirahat. Pengambilan data dilakukan besok harinya pada waktu istirahat secara bersamaan.

Analisis data dalam penelitian ini menggunakan analisis Koefisien korelasi Kendall's Tau. Analisis ini digunakan dalam mencari hubungan dan menguji hipotesis dari dua variabel atau lebih, dengan data berskala ordinal.

\section{Hasil}

Data yang didapatkan dengan analisis univariat dan bivariat sebagai berikut:

\section{Analisa Univariat}

Analisis ini dilakukan untuk menggambarkan karakteristik responden berdasarkan umur dan jenis kelamin, hasil distribusi kuliah entrepreneurship dan distribusi minat menjadi entrepreneur.

Tabel 1. Distribusi Frekuensi Responden Berdasarkan Umur dan Jenis Kelamin Mahasiswa Kebidanan di STIKES Bina Usada Bali Tahun 2019

\begin{tabular}{ll}
\hline Karakteristik & F $(\%)$ \\
\hline Umur & \\
$\mathbf{1 8}$ tahun & $15(40,6)$ \\
$\mathbf{1 9}$ tahun & $16(43,2)$ \\
$\mathbf{2 0}$ tahun & $6(16,2)$ \\
\hline Jenis Kelamin & \\
Perempuan & $37(100)$ \\
Laki-laki & $0(0)$ \\
\hline
\end{tabular}

Berdasarkan tabel 1 di atas dapat diketahui dari 37 responden yang berpartisipasi dalam penelitian ini , didominasi oleh mahasiswa yang berumur 19 tahun sebanyak 16 responden $(43,2 \%)$ dan jenis kelamin keseluruhan responden yaitu perempuan sebanyak 37 responden $(100 \%)$

Tabel 2. Distribusi Frekuensi Karakter Entrepreneurship Mahasiswa Kebidanan di STIKES Bina Usada Bali.

\begin{tabular}{lll}
\hline Variabel & f & $\%$ \\
\hline Karakter Entrepreneurship & & \\
$\quad$ Tinggi & & \\
Sedang & 8 & 21,6 \\
Rendah & 16 & 43,2 \\
\hline
\end{tabular}

Median(IQR): 43(10) $13 \quad 35,1$

Berdasarkan tabel 2 di atas dapat diketahui responden yang memiliki karakter entrepreneurship dengan tingkat yang tinggi yaitu sebanyak 8 responden $(21,6 \%)$.

Tabel 3. Distribusi Frekuensi Minat Entrepreneur Mahasiswa Kebidanan di STIKES Bina Usada Bali.

\begin{tabular}{|c|c|c|c|}
\hline \multicolumn{2}{|c|}{ Variabel } & $\mathbf{F}$ & $\%$ \\
\hline $\begin{array}{l}\text { Minat Entrepreneursh } \\
\text { Tinggi }\end{array}$ & & & \\
\hline Sedang & 18 & 48,6 & \\
\hline Rendah & 3 & 8,1 & \\
\hline Median(IQR): 22 (6) & 16 & 43,2 & \\
\hline
\end{tabular}

Berdasarkan tabel 3 di atas dapat diketahui responden paling banyak memiliki minat sedang menjadi entrepreneur yaitu sebanyak 18 responden $(48,6 \%)$.

\section{Analisis Bivariat}

Analisis Bivariat ini ditujukan untuk mengetahui hubungan karakter entrepreneurship terhadap minat mahasiswa keperawatan angkatan VIII STIKES Bina Usada Bali menjadi entrepreneur. Hasil analisis Karakter Entrepreneurship terhadap Minat Entrepreneurhip dijelaskan dalam table sebagai berikut:

Tabel 4. Karakter Entrepreneurship terhadap Minat Entrepreneurship

\begin{tabular}{llll}
\hline \multirow{2}{*}{ Variabel } & \multicolumn{3}{l}{ Minat Entrepreneurship } \\
\cline { 2 - 4 } & \multicolumn{1}{l}{ Tinggi } & Sedang & Kurang \\
\hline Karakter & & & \\
Entrepreneurship & & & \\
$\quad$ Tinggi & $8(44,4)$ & $0(0,0)$ & $0(0,0)$ \\
$\quad$ Sedang & $10(55,6)$ & $3(100,0)$ & $3(18,8)$ \\
Kurang & $0(0,0)$ & $0(0,0)$ & $13(81,3)$ \\
\hline
\end{tabular}

Berdasarkan tabel 4 di atas dapat diketahui karakter responden tinggi memiliki minat entrepreneur sebanyak 8 responden $(44,4 \%)$, pada karakter entrepreneurship sedang sebanyak 10 responden yang memiliki minat entrepreneur tinggi, 3 responden memiliki minat sedangdan 3 responden minat entrepreneurnya kurang dan untuk karakter entrepreneurship yang kurang ternyata diperoleh minat entrepreneur yang kurang juga sebanyak 13 responden.

Tabel 5. Analisis Hubungan Karakter Entrepreneurship terhadap Minat Entrepreneurship

\begin{tabular}{ll}
\hline \multicolumn{2}{c}{ Hasil Analisis Kendall's Tau } \\
\hline $\mathrm{N}$ & 37 \\
\hline Koefisien Korelasi & 0,775 \\
\hline
\end{tabular}


Sig. (2 tailed)

0,000

Berdasarkan hasil pada tabel 5 di atas diperoleh nilai korelasi Kendall's Tau sebesar 0,775 menunjukkan tingkat hubungan positif yang kuat dengan nilai $\mathrm{p}=$ 0,00 atau lebih kecil dari $\alpha=0,05(\mathrm{p}<0,05)$, yang berarti ada hubungan yang signifikan antara karakter entrepreneurship terhadap minat mahasiswa kebidanan STIKES Bina Usada menjadi seorang entrepreneur.

\section{Pembahasan}

Dalam penelitian ini yang dijadikan subjek penelitian adalah mahasiswa kebidanan STIKES Bina Usada Bali tahun 2019. Di lihat dari hasil frekuensi karakter entrepreneurship diketahui bahwa sebanyak 8 mahasiswa $(21,6 \%)$ memiliki karakter entrepreneurship dengan tingkat tinggi, 16 mahasiswa $(43,2 \%)$ pada tingkat sedang dan 13 mahasiswa $(35,1 \%)$ tidak memiliki karakter entrepreneurship. Ini berarti ada beberapa mahasiswa yang sudah memiliki karakter entrepreneur seperti bertanggung jawab terhadap pekerjaan yang dilakukan, berani mengambil risiko dengan penuh perhitungan, kreatif dan inovatif, pantang menyerah dan tidak takut gagal setelah mendapatkan pendidikan entrepreneurship. Karakter entrepreneurship yang telah dimiliki oleh para mahasiswa ini sudah sesuai dengan teori yang dijelaskan oleh Hery (2017) bahwa menjadi seorang entrepreneur pasti memiliki 12 karakteristik tersebut.

Di lihat dari hasil frekuensi minat menjadi entrepreneur diketahui 18 mahasiswa $(48,6 \%)$ memiliki minat entrepreneur yang tinggi, 3 mahasiswa $(8,1 \%)$ pada tingkat sedang dan 16 mahasiswa $(43,2 \%)$ memiliki minat entrepreneur yang rendah. Menurut Djaali (2008), minat adalah suatu rasa lebih suka dan rasa ketertarikan pada suatu hal atau aktivitas tanpa ada yang menyuruh. Minat entrepreneur mahasiswa muncul dari pengalaman yang diberikan pada waktu pendidikan entrepreneurship bahwa seorang wirausaha atau entrepreneur dapat membantu pemerintah untuk mengurangi pengangguran di Indonesia dengan cara menciptakan lapangan kerja sendiri dan dapat membuka lapangan pekerjaan bagi sumber daya manusia yang membutuhkan.

Penelitian ini sejalan dengan hasil penelitian terdahulu yang dilakukan oleh Ahmad Tri Atmaja (2016) menjelaskan bahwa adanya pengaruh antara pendidikan kewirausahaan terhadap minat berwirausaha mahasiswa Universitas Negeri Semarang. Besarnya pengaruh secara parsial sebesar $14,98 \%$ yang dlihat dari perhitungan koefisien determinasi parsial (r2). Dengan hasil penelitian ini, maka dapat dijelaskan bahwa semakin baik pendidikan kewirausahaan yang diterima mahasiswa maka semakin baik pula minat berwirausaha mahasiswa Universitas Negeri Semarang.

Analisis mengenai hubungan karakter entrepreneurship terhadap minat mahasiswa kebidanan STIKES Bina Usada menjadi entrepreneur menggunakan uji statistik dengan korelasi Kendall's Tau diperoleh hasil nilai korelasi sebesar 0,775 menunjukkan tingkat hubungan positif yang kuat dengan nilai $\mathrm{p}=0,00$ atau lebih kecil dari $\alpha=0,05(\mathrm{p}<0,05)$, yang berarti ada hubungan yang signifikan antara karakter entrepreneurship dengan minat mahasiswa STIKES Bina Usada menjadi seorang entrepreneur.

\section{Kesimpulan}

Hasil penelitian menunjukkan bahwa terdapat hubungan yang signifikan antara karakter entrepreneurship terhadap minat mahasiswa kebidanan STIKES Bina Usada menjadi seorang entrepreneur. Diharapkam dengan adanya karakter entrepreneurship yang memunculkan minat menjadi entrepreneur semakin banyak munculnya lapangan pekerjaan baru sehingga mengurangi pengangguran.

Penelitian ini memiliki keterbatasan dari jumlah responden yang diteliti dan jenis kelamin responden yang hanya berjenis kelamin perempuan sehingga tidak bisa dibandingkan.

\section{Daftar Pustaka}

Atmaja, T. A., \& Margunani (2016). Pengaruh Pendidikan Kewirausahaan dan Aktivitas Wirausaha terhadap Minat Berwirausaha Mahasiswa Universitas Negeri Semarang. Economic Education Analysis Journal, 5(3). Hal. 774-787

Agustiyani. (2014). Pengaruh pembelajaran mata kuliah kewirausahaan terhadap minat mahasiswa untuk berwirausaha (studi kasus pada mahasiswa program studi Ekonomi Islam angkatan tahun 2011 UIN Walisongo Semarang). http://eprints.walisongo.ac.id/3590/. Sitasi Agustus 2017

Depkop. (2017). Ratio Wirausaha Indonesia Naik Jadi 3,1 Persen.

Djaali. (2007). Psikologi Pendidikan. Jakarta: Bumi Aksara 
http://www.dpr.go.id/dokakd/dokumen/RJ120171109-024117-1121.pdf

https://pusdatin.kemkes.go.id/resources/download/p usdatin/profil-kesehatan-indonesia/Data-danInformasi_Profil-Kesehatan-Indonesia-2018.pdf

https://www.neliti.com/id/publications/206714/peng aruh-pendidikan-kewirausahaan-terhadapminat-berwirausaha-mahasiswa-fakultas

Hery. (2017). Kewirausahaan. Jakarta. PT Grasindo.

Nursalam, (2013). Manajemen Keperawatan. Jakarta: Salemba Medika

Kasmir. (2013). Kewirausahaan. Jakarta: Raja Grafindo Persada.

Rahmadi, N. A. (2016). Analisis Faktor - Faktor Yang Mempengaruhi Minat Berwirausaha Pada Mahasiswa Studi Manajemen Fakultas Ekonomi Universitas Kadiri.

Sugiyono. (2014). Metode Penelitian Kuantitatif, Kualitatif dan R\&D. Bandung: Alfabeta

Suryana. (2013). Kewirausahaan Kiat dan Proses Menuju Sukses. Jakarta: SALEMBA EMPAT.

Wirajaya, I. G. (2018). "Pengaruh Kuliah Entrepreneurship Terhadap Minat Mahasiswa Keperawatan STIKES Bina Usada Angkatan VIII Menjadi Seorang Entrepreneur". https://ojs.ikippgribali.ac.id/index.php/widyadar i/article/download/188/157/ 